\title{
Pengaruh Model Pembelajaran SSCS (Search, Solve, Create, and Share) terhadap Kemampuan Koneksi Matematis Siswa SMA Negeri 45 Jakarta
}

\author{
Orbitha Khaillasiwi ${ }^{1,}$ a), Swida Purwanto ${ }^{2, b)}$, Meiliasari $^{3,}$ c) \\ ${ }^{123}$ Program Studi Pendidikan Matematika, FMIPA, Universitas Negeri Jakarta \\ Email: a)okhailla.ok@gmail.com
}

\begin{abstract}
Abstrak
Kemampuan koneksimatematis ia lah kema mpuan untuk mengaitkan konsep -konsep da lam matematika, mengaitkan konsep matematika dengan disiplin ilmu lai, serta dengan permasalahan dalam kehidupan nyata. Kemampuan koneksi matematis erat kaitannya dengan kemampuan pemecahan masalah. Apabila kemampuan koneksi ma tematis yang dimiliki kurang, maka sa at menyelesaikan suatu permasalahan pun akan mengalami kesulitan. Penelitian ini bertujuan untuk mengetahui pengaruh model pembelajaran SSCS (Search, Solve, Create, and Share) terhadap kemampuan koneksi matematis siswa. Penelitian dilaksanakan di SMA Negeri 45 Jakarta pada siswa kelas XI MIPA tahun ajaran 2018/2019 dengan pokok bahasan turunan fungsi aljabar. Metode penelitian yang digunakan adalah metode eksperimen semu, yang melibatkan 62 siswa sebagai sampel. Pengambilan sampel menggunakan teknik cluster random sampling. Instrumen penelitian yang digunakan berupa tes akhir kema mpuan koneksi matematis yang terdiri dari 4 soal uraian. Pengujian hipotesis menggunakan uji-t'dengan taraf signifikansi 0,05 . Berdasarkan hasil perhitungan hipotesis, diperoleh $t_{\text {hitung }}=3,842>1,697=t_{0,05 ; 51}$ sehingga tolak $\mathrm{H}_{0}$, artinya rata-rata hasil tes kemampuan koneksi matematis siswa kelas eksperimen secara signifikan lebih tinggi dari kelas kontrol. Dengan demikian, dapat disimpulkan bahwa modelpembelajaran SSCS (Search, Solve, Create, and Share) berpengaruh terhadap kemampuan koneksi matematis siswa SMA Negeri 45 Jakarta. Pengaruh yang diberikan termasuk ke dalam kategori tinggi yaitu sebesar $84 \%$ berdasarkan perhitungan dengan Cohen's effect size.
\end{abstract}

Kata kunci: kemampuan koneksi matematis, model SSCS.

\section{PENDAHULUAN}

Matematika merupakan ilmu universal yang menjadi pondasi dari perkembangan teknologi modern, serta mempunyai peran penting dalam berbagai disiplin dan memajukan daya pikir manusia. Dalam bidang pendidikan, diajarkannya matematika dari jenjang pendidikan dasar hingga pendidikan menengah bertujuan untuk membekali siswa dengan kemampuan berpikir logis, analitis, sistematis, kritis, dan kreatif, serja kemampuan bekerjasama. Berbagai usah a telah dilakukan pemerintah untuk mencapai tujuan tersebut. Namun, usaha yang dilakukan belum dapat dikatakan berhasil karena pencapaian hasil belajar siswa di mata pelajaran matematika masih rendah ditinjau dari rata-rata nilai Ujian Nasional (UN) SMA pada tahun 2018. Perolehan hasil UN tersebut tentu tidak terlepas dari kemampuan matematis yang dimiliki oleh siswa. Salah satu standar proses yang dapat mempengaruhi hasil belajar menurut Sulistyaningsih (2014: 15) adalah kemampuan koneksi matematis.

Koneksi dalam matematika menurut Eli (2013: 122) adalah sebuah penghubung atau jembatan antara pengetahuan yang lama dengan pengetahuan yang baru digunakan untuk membangun serta memperkuat pemahaman tentang hubungan antara konsep-konsep matematika, atau representasi matematisnya. Sedangkan kemampuan koneksi matematis menurut Widarti (2013: 2) ialah kemampuan siswa dalam mencari hubungan suatu representasi konsep dan prosedur, memahami 
gagasan antar topik matematika, dan kemampuan siswa mengaplikasikan konse p matematika dalam bidang lain atau dalam kehidupan sehari-hari. Berdasarkan penjelasan tersebut dapat disimpulkan kemampuan koneksi matematis adalah kemampuan untuk menggunakan serta memahami hubungan antarkonsep, ide, maupun topik dalam matematika, serta menggunakan representasi matematikadalam bidang ilmu lain dan dalam kehidupan sehari-hari.

Berdasarkan hasil observasi di SMA Negeri 45 Jakarta, model pembelajaran yang sering digunakan dalam pembelajaran matematika di kelas kurang menimbulkan keaktifan siswa. Hal tersebut dikarenakan pembelajaran yang masih berpusat pada guru. Padahal menurut kurikulum 2013, pembelajaran haruslah berpusat pada siswa dan menggunakan model pembelajaran yang berbasis pada masalah. Akibat dari tidak dibiasakannya siswa diberikan suatu permasalahan matematis, akan berdampak pada kemampuan koneksi matematis yang dimiliki siswa. Rendahnya kemampuan koneksi matematis siswa di sekolah tersebut dapat dilihat dari bagaimana siswa menyelesaikan persoalan sebagai berikut:

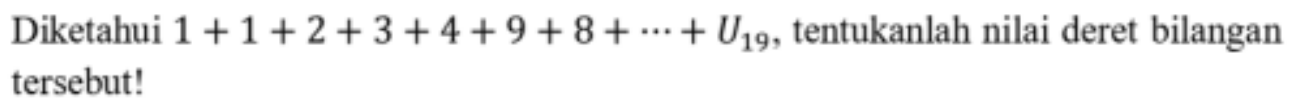

GAMBAR 1. Soal Kemampuan Koneksi Matematis

Siswa yang memiliki kemampuan koneksi matematis yang baik akan menyelesaikannya dengan membagi deret tersebut menjadi deret suku ganjil dan genap. Namun, sebagaian besar siswa menjawabnya dengan cara menjumlahkan semua suku secara manual.

Berdasarkan beberapa permasalahan di atas, maka diperlukan adanya upaya yang efektif untuk mengatasi permasalahan tersebut. Salah satu model pembelajaran yang dapat mempengaruhi kemampuan koneksi matematis siswa adalah model pembelajaran SSCS (Search, Solve, Create, and Share). Terdapat empat tahapan pembelajaran pada model pembelajaran SSCS ini, yaitu search (mengidentifikasi masalah), solve (merancang solusi), create (memformulasikan hasil), dan share (mengkomunikasikan hasil).

Model pembelajaran SSCS dikembangkan oleh Pizzini pada tahun 1987 sebagai model pembelajaran yang berdasarkan pada pemecahan masalah, hal ini dikarenakan pada awal pembelajaran disajikan suatu masalah matematis yang kemudian melalui penalaran induktif siswa menemukan kembali konsep yang dipelajari dan kemampuan matematis lainnya. Pengembangan model pembelajaran SSCS bertujuan untuk mengajarkan proses pemecahan masalah serta memberikan kesempatan siswa untuk berlatih dan menyempurnakan keterampilan mereka dalam menyelesaikan masalah (Pizzini, 1988: 23). Pada awalnya model SSCS diterapkan hanya pada pelajaran sains, akan tetapi melalui berbagai penyempurnaan menjadikan model ini dapat diterapkan pada pelajaran matematika dan sains (Irwan, 2011: 10). Hal ini berarti bahwa dalam pembelajaran matematika, guru dapat menerapkan model SSCS sebagai salah satu alternatif dalam merancang pembelajaran yang inovatif.

Pizzini merancang model pembelajaran SSCS dengan empat tahapan pembelajaran, yaitu search, solve, create, and share seperti yang terlihat pada Gambar 2.

a. Tahap Search

Pada tahap search siswa akan mengungkapkan pendapat dan menghasilkan ide-ide yang berhubungan dengan masalah yang diberikan agar dapat, mengidentifikasi dan mengin vestigasi masalah. Dalam hal menyelesaikan masalah, siswa harus mampu menghubungkan masalah yang telah dimiliki dengan konsep-konsep yang telah dipelajari sebelumnya. Pada tahap ini, siswa mengidentifikasi apa saja yang diketahui dan ditanyakan pada masalah, memeriksa kelengkapan data yang akan digunakan untuk menyelesaikan masalah serta menulis pertanyaan-pertanyaan singkat berhubungan dengan masalah. Dengan demikian, pada tahap search, kemampuan koneksi matematis siswa dirangsang sehingga siswa mampu menemukan keterkaitan konsep-konsep yang dipelajari sebelumnya.

b. Tahap Solve

Tahap solve bertujuan untuk merencanakan dan melaksanakan penyelesaian masalah dengan melihat kembali informasi yang telah ditemukan pada tahap search. Siswa memilih langkah- 
langkah penyelesaian masalah. Dalam hal ini siswa juga mengembangkan kemampuan koneksi matematis dalam hal memilih konsep-konsepyang terkait. Sementara itu, kegiatan guru padatahap ini ialah membimbing siswa membuat perancangan penyelesaian masalah.

c. Tahap Create

Pada tahap create, siswa menerapkan rancangan yang dibuat untuk menyelesaikan masalah, menciptakan atau menemukan penyelesaian dari masalah dan memperoleh kesimpulan. Kemampuan koneksi matematis siswa pada tahap ini dapat terlihat dari jawaban siswa dalam memecahkan suatu permasalahan yang diberikan, sudah menunjukkan keterkaitan yang sesuai atau belum.

d. Tahap Share

Tahap terakhir dari model pembelajaran SSCS ialah tahap share, dimana pada tahap ini siswa mengartikulasikan pemikirannya melalui komunikasi dan interaksi dengan temannya, menerima dan memproses umpan balik, serta merefleksikan dan mengevaluasi solusi dan jawaban yang dibuatnya. Siswa dapat mengomunikasikannya dengan berdiskusi bersama guru, teman sekelompok ataupun dilakukan dengan diskusi antar kelompok. Sementara itu, kegiatan guru adalah memberikan penguatan atas kebenaran jawaban yang dikemukakan oleh siswa dan mengevaluasi jawaban siswa. Kegiatan diskusi pada tahap ini pada akhirnya dapat membangun koneksi matematis siswa.

Model pembelajaran SSCS dikembangkan oleh Pizzini (1988) pada mata pelajaran sains, dimana model tersebut merupakan model pembelajaran yang dimulai dengan pemberian masalah. Walaupun

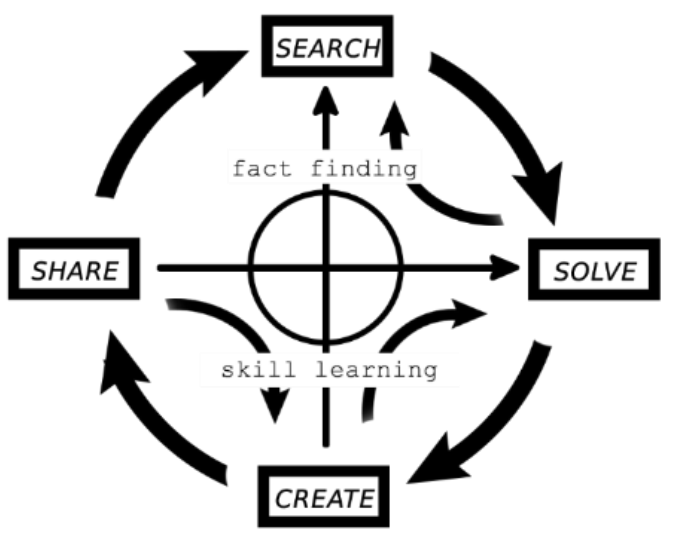

GAMBAR 2. Siklus Model Pembelajaran SSCS

dikembangkan untuk pembelajaran sains, ternyata model pembelajaran SSCS menarik perhatian peneliti lain untuk menerapkannya pada pembelajaran matematika. Salah satunya adalah Irwan (2011) yang menerapkan model pembelajaran SSCS untuk mengetahui pengaruhnya terhadap kemampuan penalaran matematis. Selain kemampuan penalaran matematis, ternyata kemampuan lain seperti berpikir logis matematis siswa juga dapat meningkat dengan penerapan model pembelajaran SSCS (Kurniawati dan Fatimah, 2014). Namun, belum ada penelitian terkait pengaruh model pembelajaran SSCS terhadap kemampuan koneksi matematis siswa. Sedangkan, ,enurut laporan Laboratory Network Program (1994) terdapat beberapa standar NCTM yang dapat dicapai dengan menerapkan model pembelajaran SSCS, salah satunya adalah dapat merangsang siswa membuat koneksi. Selain itu, menurut hasil penelitian Mahendra (2016) kemampuan koneksi matematis dapat meningkat dengan menerapkan model pembelajaran Problem Based Learning (PBL). Model pembelajaran tersebut memiliki kesamaan dengan model pembelajaran SSCS yaitu pemberian masalah matematis di awal pembelajaran. Hal ini menjadi dasar peneliti untuk melakukan penelitian terkait penerapan model pembelajaran SSCS dan pengaruhnya terhadap kemampuan koneksi matematis.

$\operatorname{NCTM}(2000: 359)$ menyatakan bahwakemampuankoneksi matematis siswadapat dikembangkan dan dilatih melalui pemberian masalah yang dapat diselesaikan dengan memanfaatkan keterkaitan antar konsep matematika atau secara umumnya masalah tersebut merupakan pengembangan dari indikator koneksi matematis. Adapun indikator koneksi matematis yang dipakai dalam penelitian ini, 
yaitu: (1) mengaitkan konsep-konsep dalam matematika, (2) mengaitkan matematika dalam penyelesaian masalah yang muncul pada disiplin ilmu lain, dan (3) mengaitkan konsep matematika dengan masalah kehidupan sehari-hari.

Salah satu pokok bahasan yang menjadi permasalahan bagi siswa SMA Negeri 45 Jakarta adalah turunan fungsi aljabar. Berdasarkan hasil UN SMA di sekolah tersebut, daya serap siswa paling rendah berada pada pokok bahasan turunan fungsi aljabar, terutama untuk tipe soal yang berkaitan dengan penerapan turunan fungsi aljabar.

\section{METODE}

Penelitian ini merupakan penelitian eksperimen semu yang menggunakan desain Posttest Only Control Group.

TABEL 1. Desain Penelitian

\begin{tabular}{ccc}
\hline Kelas & Perlakuan & Posttest \\
\hline Eksperimen & $\mathrm{X}$ & $\mathrm{Y}$ \\
\hline Kontrol & - & $\mathrm{Y}$ \\
\hline
\end{tabular}

Keterangan:

X : Model pembelajaran SSCS

Y : Posttest kemampuan koneksi matematis

Penelitian dilakukan dengan cara memberikan perlakuan terhadap subyek penelitian berupa pembelajaran yang berbeda, sehingga penelitian ini menggunakan dua kelas yaitu kelas eksperimen dan kelas kontrol. Kelas eksperimen akan diberi perlakuan berupa model pembelajaran SSCS dan kelas kontrol menggunakan model pembelajaran konvensional. Populasi terjangkau dalam penelitian ini adalah seluruh siswa kelas XI SMA Negeri 45 Jakarta tahun ajaran 2018/2019. Pengambilan sampel dilakukan menggunakan teknik two stage random sampling. Tahap pertama menggunakan simple random sampling untuk menentukan program studi MIPA atau IPS yang akan terpilih. Tahap kedua menggunakan simple random sampling untuk menentukan kelas eksperimen dan kelas kontrol dari empat kelas XI MIPA dari hasil tahap pertama. Kelas eksperimen dan kelas kontrol diharapkan memiliki kondisi awal yang sama, sehingga dilakukan uji normalitas, homogenitas, dan uji kesamaaan rata-rata. Kemudian dari uji-uji tersebut diperoleh kelas XI MIPA 2 sebagai kelas eksperimen, dan kelas XI MIPA 1 sebagai kelas kontrol.

Pengumpulan data dilakukan melalui tes kemampuan koneksi matematis yang dilakukan di akhir pertemuan. Tes ini bertujuan untuk mengukur kemampuan koneksi matematis siswa pada pokok baahasan turunan fungsi aljabar. Instrumen tes berupa soal uraian yang terdiri dari empat soal yang sudah melalui uji validitas isi, validitas konstruk, validitas empiris, reliabilitas, dan taraf kesukaran soal. Data tes kemampuan koneksi matematisdianalisis secarakuantitatif yang diawali dengan menguji kenormalan dan kehomogenan sebagai dasar dalam pengujian hipotesis statistik. Setelah dilakukan uji hipotesis, selanjutnya ialah menghitung besar pengaruh menggunakan Cohen's effect size. Adapun hipotesis statistik dalam penelitian ini yaitu:

$$
\begin{aligned}
& H_{0}: \mu_{1} \leq \mu_{2} \\
& H_{1}: \mu_{1}>\mu_{2}
\end{aligned}
$$

Keterangan:

$\mu_{1}$ : Rata-rata skor kemampuan koneksi matematis siswa kelas eksperimen.

$\mu_{2}$ : Rata-rata skor kemampuan koneksi matematis siswa kelas kontrol.

\section{HASIL DAN PEMBAHASAN}

Data penelitian ini diperoleh dari dua kelas di SMA Negeri 45 Jakarta, yaitu kelas XI MIPA 2 dan XI MIPA 1 yang masing-masing berjumlah 31 orang. Data diambil dari 62 dari 72 siswa dikarenakan 5 siswa dari masing-masing kelas tidak memenuhi kehadiran di dalam kelas. Data yang diperoleh 
adalah nilai hasil tes kemampuan koneksi matematis sesudah diberi perlakuan. Rata-rata tes kemampuan koneksi matematis siswa kelas eksperimen dan kelas kontrol masing-masing secara berurutan ialah 64,31 dan 49,40.

Sebelum melakukan uji hipotesis, terlebih dahulu dilakukan uji normalitas. Kegunaan uji normalitas setelah perlakuan ialah untuk menentukan metode yang digunakan dalam menguji hipotesis statistik. Jika data tidak normal, hipotesis statistik diuji menggunakan Mann Whitney-U. Namun, jika data normal, hipotesis statistik diuji menggunakan uji-t $t$ Hasil pengujian uji normalitas menggunakan Saphiro Wilk pada taraf signifikansi $\alpha=0,05$ dapat dilihat pada tabel di bawah ini.

TABEL 2. Hasil Uji Normalitas

\begin{tabular}{cccccc}
\hline Kelas & $\mathbf{N}$ & $\boldsymbol{W}_{\text {hitung }}$ & $\boldsymbol{W}_{\text {tabel }}$ & Keterangan & Keputusan \\
\hline Eksperimen & 31 & 0,950 & 0,929 & $W_{\text {hit }}>W_{\text {tab }}$ & Terima $\mathrm{H}_{0}$ \\
Kontrol & 31 & 0,934 & 0,929 & $W_{\text {hit }}>W_{\text {tab }}$ & Terima $\mathrm{H}_{0}$ \\
\hline
\end{tabular}

Berdasarkan tabel di atas, keputusan dari uji normalitas adalah menerima $\mathrm{H}_{0}$. Artinya baik kelas eksperimen maupun kelas kontrol berdistribusi normal. Oleh sebab itu, metode yang digunakan untuk menguji hipotesis statistik ialah uji-t. Namun, uji-t terbagi menjadi dua berdasarkan kehomogenan variannya. Sehingga, setelah dilakukan uji normalitas selanjutnya dilakukan uji homogenitas. Adapun metode yang digunakan untuk menguji kehomogenan varian ialah uji Fisher, karena sampel terbagi menjadi dua kelompok. Hasil uji homogenitas dapat dilihat pada tabel di bawah ini.

TABEL 3. Hasil Uji Homogenitas

\begin{tabular}{cccccc}
\hline Kelas & $\mathrm{dk}$ & $s_{i}^{2}$ & $\mathrm{~F}_{\text {hitung }}$ & $F_{0,025(30,30)}$ & $F_{0,975(30 ; 30)}$ \\
\hline Eksperimen & 30 & 331,23 & 2,429 & 2,074 & 0,482 \\
Kontrol & 30 & 136,34 & & & \\
\hline
\end{tabular}

Berdasarkan Tabel 3. Dapat dilihat bahwa nilai $F_{\text {hitung }}=2,429$ tidak berada pada daerah penerimaan $\mathrm{H}_{0}$ yaitu $0,482<F_{\text {hitung }}<2,074$. Sehingga dapat disimpulkan bahwa kedua kelas tidak memiliki varian yang homogen. Selanjutnya untuk menguji hipotesis statistik digunakan uji dengan varian yang tidak sama. Kriteria pengujian adalah tolak $\mathrm{H}_{0}$ jika $t_{h i t}>t_{\alpha ; v}$. Berdasarkan perhitungan, diperoleh nilai $t_{\text {hit }}=3,842>1,675=t_{0,05 ; 51}$. Karena $t_{\text {hit }}>t_{\alpha ; v}$, maka $\mathrm{H}_{0}$ ditolak, artinya rata-rata kemampuan koneksi matematis siswa kelas eksperimen secara signifikan lebih tinggi daripada kemampuan koneksi matematis siswa kelas kontrol. Selanjutnya perhitungan besar pengaruh menggunakan Cohen's effect size memberikan hasil sebesar 84\%. Dengan demikian penerapan model pembelajaran SSCS mempengaruhi kemampuan koneksi matematis siswa SMA Negeri 45 Jakarta dengan besar pengaruh $84 \%$. Hasil tersebut sesuai dengan pernyataan dari North Central Laboratory Network Program yang menyatakan bahwa dengan menerapkan model pembelajaran SSCS dalam pembelajaran matematika dapat merangsang siswa melakukan koneksi matematis.

Penyebab munculnya perbedaan nilai rata-rata antara lain karena peranan guru, siswa, suasana belajar, serta model pembelajaran yang digunakan. Berdasarkan teori, model pembelajaran SSCS merupakan pembelajaran yang berpusat pada siswa, melatih siswa menyelesaikan suatu permasalahan dengan tahapan atau langkah penyelesaian secara mandiri. Dalam penelitian ini yang terjadi adalah guru memberikan LKS berisi permasalahan matematis kepada siswa yang dapat diselesaikan dengan menggunakan koneksi matematis. Kemudian siswa menyelesaikannya dalam diskusi kelompok. Setiap awal pembelajaran di kelas eksperimen, guru tidak menjelaskan materi pelajaran terlebih dahulu sehingga siswa mengkonstruk pengetahuannya sendiri. Peran guru ialah sebagai fasilitator yang membimbing siswa dalam kegiatan diskusi kelompok. Melalui diskusi kelompok membantu siswa untuk mengkoneksikan materi yang telah dipelajari sebelumnya maupun dengan penerapannya dalam disiplin ilmu lain. Hal ini sesuai dengan hasil penelitian dari Rahmawati yang menyatakan bahwa dengan diskusi kelompok siswa dapat saling berinteraksi, bertanya, mengumpulkan informasi dan ideide sehingga dapat dikoneksikan dengan materi yang sudah dipelajari baik berupa konsep, definisi, atau aturan sehingga dapat menyelesaikan permasalahan yang diberikan 
Lain hal dengan pembelajaran konvensional dimana guru merupakan sumber dari proses pembelajaran. Siswa kelas kontrol cenderung bersikap pasif dan hanya mendengarkan pemaparan materi oleh guru sehingga kemampuan koneksi matematisnya tidak berkembang dan jawaban siswa ketika mengerjakan soal-soal latihan yang diberikan cenderung mengikuti langkah-langkah yang guru berikan di contoh soal.

Menurut NCTM, salah satu cara untuk mengembangkan kemampuan koneksi matematis adalah dengan memberikan suatu permasalahan matematika yang dapat diselesaikan dengan menggunakan koneksi matematis. Selain itu, kemampuan koneksi matematis dapat dilatih dengan menerapkan proses pembelajaran yang berlandaskan pada paham konstruktivisme. Dalam penelitian ini peneliti melihat kedua cara tersebut dapat terpenuhi dengan menerapkan model pembelajaran SSCS.

Berdasarkan rangkaian kegiatan pembelajaran yang terjadi di kelas eksperimen dan kelas kontrol serta perannya terhadap kemampuan koneksi matematis siswa, maka wajar jika rata-rata kemampuan koneksi matematis siswa kelas eksperimen lebih tinggi dari kelas kontrol. Hal tersebut sesuai dengan hasil penelitian dari Irwan yang menyatakan bahwa dengan menerapkan model pembelajaran SSCS, siswa dapat memanfaatkan kemampuan masalahnya dalam upaya menghubungkan situasi yang diberikan, dengan katalain kemampuan koneksi matematis dapat dikembangkan melalui pembelajaran SSCS. Lebih rinci, tahapan model pembelajaran SSCS yang dapat mengembangkan koneksi matematis siswa ialah tahap create. Hal tersebut sesuai dengan hasil temuan dari Lia Kurniawati yang menyatakan bahwa pada tahap create siswa mengkonstruk pengetahuan yang dimiliki untuk mengidentifikasi dan menganalisis hasil dari tahap sebelumnya dan dihubungkan dengan konsep yang berarti. Dengan demikian, model pembelajaran SSCS (Search, Solve, Create, and Share) memiliki pengaruh terhadap kemampuan koneksi matematis siswa SMA Negeri 45 Jakarta.

Meskipun model pembelajaran SSCS memiliki pengaruh terhadap kemampuan koneksi matematis siswa, akan tetapi nilai rata-rata yang diperoleh cukup rendah jika dibandingkan dengan Kriteria Ketuntasan Minimal yang ditetapkan oleh sekolah yaitu 75. Hal ini dikarenakan tidak semua siswa terlibat dalam proses pembelajaran di kelas. Misalnya pada saat diskusi kelompok, terdapat beberapa kelompok yang anggotanya tidak berpartisipasi dalam diskusi, sehingga siswa tersebut tidak memahami materi yang dipelajari. Selain itu, dikarenakan guru tidak terbiasa memberikan soal-soal tentang permasalahan matematis, hal ini mengakibatkan minat baca siswa menjadi kurang sehingga siswa tidak teliti dalam membaca soal posttest. Peran guru di kelas untuk mengontrol seluruh siswa agar berpartisipasi aktif sangat diperlukan.

\section{PENUTUP}

\section{Kesimpulan}

Berdasarkan hasil penelitian, diperoleh hasil bahwa rata-rata kemampuan koneksi matematis siswa pada kelas eksperimen lebih tinggi dibandingkan kelas kontrol. Maka dari itu kesimpulan yang diperoleh dari penelitian yang dilakukan ini antara lain:

1. Nilai rata-rata kemampuan koneksi matematis siswa yang belajar menggunakan model pembelajaran SSCS (Search, Solve, Create, and Share) sebesar 64,31. Sedangkan nilai rata-rata kemampuan koneksi matematis siswa yang belajar menggunakan model pembelajaran konvensional sebesar 49,40.

2. Terdapat pengaruh yang signifikan pada pembelajaran matematika menggunakan model pembelajaran SSCS (Search, Solve, Create, and Share) terhadap kemampuan koneksi matematis siswa pada pokok bahasan turunan fungsi aljabar. Hal tersebut dapat diketahui berdasarkan hasil perhitungan uji- $t$ data independen dengan nilai $t=3,842$ dan nilai $t_{\text {tabel }}=1,675$, sehingga $\mathrm{H}_{0}$ ditolak. Artinyakemampuan koneksi matematis siswa kelas yang menerapkan model pembelajaran SSCS (Search, Solve, Create, and Share) lebih tinggi daripada kelas yang menerapkan model pembelajaran konvensional.

3. Model pembelajaran SSCS (Search, Solve, Create, and Share) memberikan pengaruh sebesar $84 \%$ terhadap kemampuan koneksi matematis siswa SMA Negeri 45 Jakarta. 


\section{UCAPAN TERIMAKASIH}

Terimakasih kepada para dosen pembimbing yang telah membimbing penulis dalam menulis artikel ini. Teirmakasih kepada guru dan staf SMA Negeri 45 Jakarta yang telah mengijinkan dan membantu penulis untuk melakukan penelitian di sekolah tersebut. Terimakasih kepada wakil kurikulum dan guru matematika SMA Negeri 72 Jakarta. Terimakasih kepada pihak-pihak yang tidak bisa disebutkan satu-per-satu yang telah membantu penulis melaksanakan penelitian ini.

\section{REFERENSI}

Eli, J. A., Mohr-Schoeder, M. J., \& Lee, C. W. (2013). Mathematical Connections and Their Relationship to Mathematics Knowledge for Teaching Geometry. School and Science Mathematics Journal, 113(3), 120-134. doi:10.1111/ssm.12009

Irwan. (2011). Pengaruh Pendekatan Problem Posing Model Search Solve Create and Share (SSCS) Dalam Upaya Meningkatkan Kemampuan Penalaran Matematis Mahasiswa Matematika. Jurnal Penelitian Pendidikan, 12(1), 1 - 13.

Kurniawati, L., \& Fatimah, B. S. (2014). Problem Solving Learning Approach Using Seach, Solve, Create, and Share (SSCS) Model and The Students Mathematical Logical Thinking Skills. Presented at International Conference on Research, Implementation and Education of Mathematics and Sciences. Universitas Negeri Yogyakarta.

Mahendra, N. R., \& Mulyono. (2016). Analisis Kemampuan Koneksi Matematis Siswa Ditinjau dari Gaya Kognitif pada Model PBL. Prosiding Seminar Nasional Matematika X UNNES.

NCTM. (2000). Principles and Standards for Schools Mathematics. Reston VA: NCTM.

Pizzini, E. L., Shepardson, D. P., \& Abell, S. K. (1988). Rethinking Thinking in the Science Classroom. The Science Teacher.

Regional Educational Laboratories. (t.thn.). Promising and Practices in Mathematics \& Science Education. Diakses dari: https://books.google.co.id/books?isbn=0788115251

Sulistyaningsih. (2014). Keefektifan Model Pembelajaran Cooperative Integrated Reading and Composition dalam Meningkatkan Kemampuan Koneksi Matematik. Jurnal Karya Pendidikan Matematika, 1(1), 14-23. doi: https://doi.org/10.26714/jkpm.1.1.2014.\%25p.

Widarti, A. (2013). Kemampuan Koneksi Matematis dalam Menyelesaikan Masalah Kontekstual Ditinjau dari Kemampuan Matematis Siswa. Jurnal Pendidikan Matematika, 1(2), 1 - 8. 